\title{
Dukungan sosial bagi penderita lupus: Dapatkah menjadi moderator bagi efek penerimaan diri terhadap rasa syukur?
}

\author{
Ayumi Nalikrama Dienillah \& Sitti Chotidjah \\ Departemen Psikologi, Fakultas Ilmu Pendidikan, Universitas Pendidikan Indonesia
}

\begin{abstract}
Abstrak
Dukungan sosial memberikan sumbangan terhadap pasien dalam proses pengobatan penyakit mereka termasuk pada penderita lupus. Keadaan penderita lupus yang mengalami berbagai perubahan secara fisik dapat memengaruhi keadaan psikologisnya. Dukungan sosial terkadang tidak memberikan pengaruh yang positif, tapi dapat juga berpengaruh negatif. Penelitian ini bertujuan untuk melihat apakah dukungan sosial dapat memoderasi penerimaan diri dan rasa syukur pada penderita lupus. Partisipan dalam penelitian ini adalah 206 penderita lupus. Hasil penelitian menunjukkan bahwa dukungan sosial dapat memoderasi penerimaan diri dan rasa syukur. Hasil ini kemudian didiskusikan.
\end{abstract}

Kata kunci: dukungan sosial, penerimaan diri, rasa syukur, penderita lupus

\begin{abstract}
Social support contributes to Lupus patients in the process of treating their diseases. The condition of lupus sufferers who experience various physical changes can affect their psychological state. Social support sometimes does not have a positive influence, but it can also have a negative effect. This study aims to see whether social support can moderate self-acceptance and gratitude for lupus sufferers. Participants in this study were 206 lupus sufferers. The results showed that social support can moderate self-acceptance and gratitude. The results were then discussed.
\end{abstract}

Kata kunci: social support, self-acceptance, gratitude, lupus sufferer

\section{Pendahuluan}

Systemic lupus erythematosus (SLE) atau disebut lupus merupakan penyakit autoimun kronis yang dapat memengaruhi berbagai sistem organ termasuk sistem saraf pusat serta dapat menyebabkan kerusakan (Prasetyo \& Kustanti, 2015; Raafat, El Refai, Alrasheed, \& El Din, 2015; Resende, Barbosa, Simões, \& Velasque, 2016). Pada tahun 2013, terdapat sekitar 13.300 penderita lupus di Indonesia (Mardiani, 2013). Penyakit lupus dapat menimbulkan perubahan fisik, seperti rambut rontok, sensitif pada sinar matahari, timbulnya bercak-bercak kemerahan pada wajah atau moon face, membengkaknya tubuh, gangguan pada perut, sakit kepala, nyeri sendi, dan sariawan di sekitar mulut (Citra \& Eriany, 2015; Paramita \& Margaretha, 2013; Prasetyo \& Kustanti, 2015). Selain berubahnya kondisi fisik, kondisi psikologis penderita lupus juga dapat mengalami perubahan. Penderita lupus dapat merasa cemas, minder, gelisah, dan depresi (Palagini, dkk., 2013; Prasetyo \& Kustanti, 2015; Figueiredo-Braga, dkk., 2018).

Oleh karena itu, penerimaan diri merupakan aspek penting yang perlu dimiliki seorang penderita lupus. Penerimaan diri adalah keadaan di mana seorang individu memiliki penilaian positif terhadap dirinya (Ryff \& Keyes, 1995). Penerimaan diri terdiri dari beberapa aspek, di antaranya adalah persepsi mengenai diri dan sikap terhadap penampilan. Pada aspek ini, individu yang menderita lupus dapat mengakui dan menerima berbagai keadaan yang ada dalam dirinya, baik yang bersifat baik, maupun buruk (Ryff dalam Desiningrum, 2014). Penelitian menunjukkan bahwa individu yang bisa menerima dirinya akan cenderung lebih terlihat mandiri dan percaya diri. Mereka tidak akan mengikuti temannya hanya untuk mendapatkan pengakuan dari teman sebayanya (Ceyhan \& Ceyhan, 2011; Meilinda, 2013). Aspek yang kedua adalah sikap terhadap kelemahan dan kekuatan diri sendiri dan orang lain. Pada penderita lupus yang sudah mampu menerima dirinya, ia dapat menilai secara realistis apa saja kemampuan dan juga keterbatasan yang dimiliki tanpa menyalahkan orang lain atau mencela dirinya sendiri atas keterbatasan dirinya (Permatasari, 2012). Selanjutnya, aspek yang ketiga adalah perasaan inferioritas sebagai gejala penolakan diri. Perasaan inferiori- 
tas merupakan sikap tidak menerima diri dan menunggu penilaian yang realistik atas dirinya.

Dengan penerimaan diri, para penderita lupus lebih mungkin akan merasa bersyukur dalam hidupnya. Rasa syukur diduga dapat menjadi variabel psikologis yang berperan bagi kesembuhan pasien lupus. Individu yang memiliki rasa syukur yang tinggi cenderung lebih banyak dipenuhi oleh emosi-emosi positif dibandingkan dengan individu yang memiliki rasa syukur rendah (Fredricksonin dalam Ramzan \& Rana, 2014). Penelitian yang dilakukan oleh Mahardika dan Halimah (2017) menunjukkan bahwa dalam keadaan sakit, penderita lupus yang masih memiliki pikiran bahwa di dalam hidupnya terdapat banyak kebaikan-kebaikan lain yang berasal dari Tuhan maupun dari orang lain dapat menghadapi kesulitan-kesulitan akibat penyakitnya. Hal tersebut sesuai dengan salah satu karakteristik seseorang yang bersyukur yaitu cenderung menyadari adanya kontribusi dari pihak lain untuk kebaikan yang terjadi di dalam kehidupannya (Peterson \& Seligman, 2004).

\section{Efek moderasi dukungan sosial}

Studi pendahuluan yang dilakukan peneliti kepada tiga orang subjek menunjukkan adanya rasa ditolak dari lingkungan sehingga mereka lebih memilih untuk menarik diri. Hal ini sesuai dengan pernyataan dari Jersild (dalam Sari \& Reza, 2013). Keadaan tersebut karena masyarakat didapati menghindar, mencemooh, dan menganggap penderita lupus lemah (Nurmalasari \& Putri, 2015), serta mereka masih kurang memahami dan memberikan motivasi kepada penderita lupus (Fitri \& Zulfan, 2018).

Keadaan penderita lupus yang demikian menunjukkan bahwa, dalam keadaan tersebut, dukungan orang-orang di sekitarnya menjadi sangat penting. Dukungan yang didapatkan oleh penderita lupus dapat membuat dirinya merasa dicintai, diperhatikan, memiliki harga diri dan bernilai, serta merasa menjadi bagian dari suatu jaringan komunitas atau keluarga yang selalu siap membantu ketika dibutuhkan (Sarafino \& Smith, 2010). Menurut Baron dan Bryne (2000), dukungan sosial merupakan kenyamanan fisik dan psikologis yang diberikan oleh teman maupun keluarga. Penerimaan diri tanpa adanya dukungan sosial, berpotensi menciptakan sikap negatif terhadap kondisi hidup seseorang.

Dukungan dari keluarga yang hangat dapat membuat individu merasa diperhatikan, nyaman, dipedulikan, dan dicintai oleh keluarga sehingga individu akan lebih mampu menghadapi masalah dengan lebih baik (Utami \& Widiasavitri, 2013). Hal ini diperkuat dengan penelitian dari Nurullah (2012) yang menunjukkan bahwa du- kungan dari pasangan berkaitan dengan tingkat stres yang rendah. Kuatnya dukungan sosial yang berasal dari relasi terdekat pasien adalah salah satu proses psikologis yang dapat membuat perilaku sehatnya terjaga (Desiningrum, 2014). Dukungan sosial merupakan aspek yang signifikan dalam menurunkan tingkat depresi pada penderita lupus. Penderita yang memiliki banyak dukungan sosial merasa percaya diri bahwa mereka mampu mengelola penyakit ini (Jordan, Thompson, Dunlop-Thomas, Lim, \& Drenkard, 2019).

Hasil penelitian lainnya menunjukkan bahwa dukungan sosial tidak selalu dirasakan dan diterima positif oleh pasien. Mereka merasa besarnya dukungan yang diberikan membuat mereka merasa tidak berdaya dan tidak dapat berfungsi dalam kehidupan sehari-hari. Penelitian oleh Moses, Wigger, Nicholas, dan Cockburn (2005) menemukan $94 \%$ pasien lupus tidak mendapatkan dukungan sosial yang mereka butuhkan sehingga menimbulkan kelelahan, rasa sakit, tidak dapat melakukan aktivitas rutin sebelumnya, ketakutan terhadap gejala sesak napas, permasalahan tidur, stress, dan cemas, juga merasa tidak berharga. Mazzoni dan Cicognani (2014) lebih lanjut mengidentifikasikan dukungan yang dirasakan bermasalah oleh pasien lupus, yaitu kekhawatiran berlebihan dan saran-saran yang tidak diinginkan, informasi yang tidak tepat terhadap kondisi klinis penyakit mereka, serta dukungan untuk mengabaikan penyakit mereka. Lebih lanjut, Mazzoni, Cicognani, dan Prati (2017) menemukan bahwa kurangnya pemahaman dan empati dari teman, anggota keluarga, dan perawat mereka dapat menyebabkan konflik dan penarikan diri dari lingkungan sosial.

Bentuk dari dukungan sosial tidak hanya satu jenis saja. Weiss dalam Cutrona \& Russell (1987) berpendapat bahwa dukungan sosial ada enam bentuk. Pertama, kelekatan (attachment), yaitu dukungan berupa perasaan kedekatan secara emosional kepada orang lain yang dirasa memberikan rasa aman. Kedua, integrasi sosial (social integration), dukungan sosial ini membuat seseorang merasa diterima, dipedulikan, dan dapat menjalani aktivitas hiburan bersama. Ketiga, bimbingan (guidance), bentuk dukungan sosial ini berupa memberikan saran atau informasi yang membantu individu dapat menyelesaikan masalah yang sedang dihadapi. Bentuk dukungan sosial keempat adalah reliable alliance, yaitu dukungan yang membuat individu yakin bahwa dirinya memiliki seseorang yang dapat diandalkan untuk membantunya. Kelima, penghargaan diri (reassurance of worth), yaitu dukungan yang dapat meningkatkan keyakinan dari penerimanya bahwa dirinya berharga dan dapat melewati atau menyelesaikan masalahnya. Bentuk dukungan sosial 
yang terakhir adalah kesempatan untuk meng-asihi (opportunity of nurturance), yaitu kesem-patan untuk menolong orang lain. Hal ini mem-buat individu merasa dibutuhkan oleh orang lain.

Bagi penderita lupus, enam bentuk dukungan sosial tersebut dibutuhkan dalam ukuran yang tepat agar mereka dapat tetap bertahan menghadapi penyakitnya. Sebagai contoh, penderita memerlukan informasi penting untuk mengetahui bagaimana gejala lupus, apa yang harus ia lakukan untuk mengobatinya, dan informasi tentang pelayanan kesehatan yang tersedia (Judha, Nurachmah, Rachmawati, 2010). Adanya dukungan berupa informasi akan membuat wawasan individu menjadi lebih luas sehingga dapat lebih berpikir positif dalam menghadapi suatu permasalahan (Sari dalam Utami \& Widiasavitri, 2013). Informasi tentang penyakit dan keadaannya itu diharapkan dapat membantu penderita lupus dalam memahami kondisi dan perubahan yang terjadi pada dirinya. Paham tentang keadaan diri (self understanding) merupakan salah satu faktor dari self-acceptance atau penerimaan diri (Novianty, 2014).

Berdasarkan hal tersebut, terlihat bahwa penerimaan diri memprediksi rasa syukur. Penderita lupus yang mampu menerima dirinya akan lebih mudah berpikir secara rasional dan dapat mencari solusi untuk akhirnya dapat tetap melanjutkan kehidupannya sehari-hari. Selain kedua variabel tersebut, dukungan sosial dapat memperkuat hubungan itu. Fenomena inilah yang membuat peneliti menjadi tertarik untuk menguji secara empiris untuk mengetahui apakah dukungan sosial dapat menjadi variabel moderator untuk penerimaan diri dan rasa syukur pada penderita lupus.

\section{Metode Penelitian}

\section{Partisipan}

Penelitian ini melibatkan 206 penderita lupus yang berobat di Rumah Sakit Hasan Sadikin (RSHS) dengan jenis kelamin perempuan. Hal tersebut dilandasi oleh ditemukannya kasus lupus yang menyerang perempuan lebih banyak daripada pada laki-laki, yaitu sebanyak $90 \%$.

\section{Tahap Penelitian}

Langkah pertama adalah mengajukan izin penelitian kepada komite etik RSHS dilanjutkan dengan pengisian formulir mengenai prosedur dari penelitian yang disediakan oleh pihak RSHS. Setelah mendapatkan persetujuan etik, peneliti membuat surat izin penelitian dari universitas yang ditujukan kepada Direktur Utama
RSHS. Setelah surat izin keluar, peneliti baru dapat ke tahapan pengambilan data.

Pada proses pengambilan data, peneliti membagikan kuesioner secara langsung kepada 206 partisipan. Pengisian dilakukan secara individual kepada pasien yang datang berobat di Poliklinik Rheumatologi RSHS Bandung setelah pasien menyatakan kesediaannya dan mengisi surat pernyataan kesediaan. Terdapat beberapa partisipan yang mengisi kuesioner dibantu oleh peneliti ataupun kerabat yang mendampinginya karena keadaan partisipan yang kurang mendukung. Setelah partisipan selesai mengisi kuesioner, peneliti memberikan kenang-kenangan berupa dompet. Pengambilan data tersebut dilakukan dari bulan Agustus hingga bulan September 2017.

\section{Desain}

Penelitian ini menggunakan pendekatan kuantitatif. Hal ini bertujuan untuk melihat apakah dukungan sosial dapat menjadi moderator untuk penerimaan diri dan rasa syukur. Pada penelitian ini, variabel-variabel tersebut diukur dengan menggunakan kuesioner berbentuk skala likert.

\section{Alat Ukur}

Sebelum digunakan untuk pengambilan data, peneliti melakukan proses alih pada ketiga alat ukur dari bahasa Inggris ke bahasa Indonesia dengan bantuan dari ahli dan melakukan proses pengecekan kelayakan item. Proses selanjutnya adalah melakukan uji coba kepada 156 orang penderita lupus.

Dukungan Sosial. Alat ukur Social Provision Scale diadaptasi Cutrona dan Russell (1987) terdiri dari 24 item dengan 12 item favourable dan 12 item lainnya unfavourable. Skala yang digunakan adalah skala likert 1-4, yaitu setuju hingga sangat tidak setuju untuk item-item yang favourable. Sedangkan untuk item-item unfavourable, skala yang digunakan adalah skala likert 14, yaitu sangat tidak setuju hingga setuju.

Hasil pengolahan data menunjukkan reliabilitas alat ukur sebesar 0,93. Contoh item dimensi guidance (bimbingan) di antaranya, "Saya memiliki seseorang yang dapat saya ajak bicara mengenai keputusan penting dalam hidup saya" untuk item favourable dan "Tidak ada seorangpun yang dapat saya andalkan ketika saya mengalami stress" untuk item unfavourable. Dimensi lainnya adalah reliable alliance (keberadaan teman yang dapat diandalkan). Contoh itemnya adalah; "Saya memiliki orang-orang yang dapat saya andalkan dalam keadaan darurat" untuk item favourable dan "Jika ada masalah yang terjadi, 
tidak ada orang yang akan membantu saya" untuk item unfavourable.

Selanjutnya, contoh item dari dimensi opportunity of nurturance (kesempatan untuk mengasuh orang lain). Pertama; "Beberapa orang tergantung pada bantuan dari saya" untuk item favourable dan kedua; "Tidak ada yang benarbenar mengandalkan saya untuk kebahagiaan mereka" untuk item unfavourable. Kemudian contoh item dari dimensi reassurance of worth (meyakinkan adanya keberhargaan diri), antara lain, "Saya memiliki hubungan dengan orang-orang yang mengakui kemampuan dan keterampilan saya" sebagai item favourable dan "Orang lain tidak menganggap saya kompeten" untuk item unfavourable. Selanjutnya, contoh item dari dimensi attachment, antara lain, "Saya memiliki hubungan yang dekat dengan seseorang yang memberi saya rasa aman secara emosional" sebagai item favourable dan "Saya kurang merasa akrab dengan orang lain" untuk item unfavourable. Dimensi yang terakhir adalah social integration (integrasi sosial). Contoh item dimensi social integration adalah "Saya memiliki orangorang yang dapat saya ajak untuk melakukan aktivitas sosial yang sama" untuk item yang favourable dan "Tidak ada seorangpun yang menjadi teman berbagi tentang minat dan kekhawatiran saya" untuk item unfavourable.

Penerimaan Diri. Alat ukur penerimaan diri dalam penelitian ini berjumlah 12 item dan menggunakan skala self-acceptance yang diadaptasi dari Hernandez (2014). Pada penelitian ini, skala self-acceptance menggunakan skala likert 1-6 dari sangat setuju hingga sangat tidak setuju untuk item favourable dan mulai dari sangat tidak setuju hingga sangat setuju untuk item unfavorable. Contoh dari item favourable alat ukur ini adalah "ketika saya mengingat kembali kisah hidup saya, saya senang dengan apa yang telah terjadi". Sedangkan, contoh unfavourable, seperti, "dalam banyak hal, saya merasa kecewa dengan prestasi yang telah saya capai dalam hidup". Setelah dilakukan uji coba, didapatkan hasil bahwa reliabilitas alat ukur ini sebesar 0,72.

Rasa Syukur. Alat ukur untuk melihat rasa syukur partisipan menggunakan The Gratitude Questionnaire-Six Item Form (GQ-6) yang diadaptasi dari McCullough, Emmons, dan Tsang (2002). Kuesioner ini terdiri dari 6 item yang mengukur rasa syukur berdasarkan dimen-si intensity (contoh itemnya adalah "Seiring bertambahnya usia, saya merasa lebih mampu menghargai orang lain, kejadian, dan situasi yang menjadi bagian dari sejarah hidup saya"); dimensi frequency (contoh itemnya adalah "Saya memiliki banyak hal dalam hidup untuk disyukuri"), dimensi span (contoh itemnya adalah "Saya tidak merasa ada hal yang dapat saya syukuri dalam kehidupan saya"), dan dimensi density (contoh itemnya adalah "Saya berterimakasih kepada orang-orang yang ada dalam kehidupan saya"). Setelah diuji coba, diperoleh hasil reliabilitas alat ukur sebesar 0,73 .

\section{Teknik Analisis}

Teknik analisis data yang digunakan dalam penelitian ini adalah analisis jalur untuk melihat apakah variabel dukungan sosial sebagai variabel moderator dapat meningkatkan atau melemahkan hubungan penerimaan diri dan rasa syukur. Sebelum melakukan regresi, data yang semula ordinal ditransformasi menjadi data interval. Hasil dari skor interval tersebut sudah dianggap data normal sehingga tidak dilakukan kembali uji normalitas.

\section{Hasil Penelitian}

Hasil dari penelitian ini menemukan beberapa temuan. Pertama, data demografis partisipan dapat dilihat dalam tabel 1.

Data partisipan yang terkumpul menunjukkan bahwa usia partisipan beragam. Terdapat 15 partisipan remaja, 141 partisipan usia dewasa awal, 33 partisipan merupakan dewasa madya, dan 17 partisipan merupakan dewasa lanjut. Sedangkan, jika dilihat dari lamanya terdiagnosis lupus, penderita lupus yang sudah 0-5 tahun menderita lupus sebanyak 127 orang, 6-10 tahun sebanyak 51 orang, dan sebanyak 28 partisipan sudah lebih dari 10 tahun menderita lupus. Selain itu, data yang didapat juga menunjukkan status pernikahan dari partisipan. Sebanyak 61 orang partisipan lajang dan 134 partisipan sudah menikah.

Penelitian ini juga menghasilkan gambaran umum mengenai partisipan untuk setiap variabel sebagaimana ditunjukkan pada tabel 2 . Tabel itu juga memperlihatkan bahwa penerimaan diri pada partisipan dibagi menjadi dua kelompok, yaitu tinggi dan rendah. Data statistik menunjukkan bahwa dari total 206 partisipan, terdapat 109 (52,9\%) partisipan yang masuk ke dalam kategori penerimaan diri tinggi. Sedangkan, sebanyak 97 (47,1\%) partisipan masuk ke dalam kategori penerimaan diri rendah.

Selain penerimaan diri, dukungan sosial pada penelitian ini juga dibagi menjadi dua kategori, yaitu dukungan sosial yang tinggi dan rendah. Dari sebanyak 206 partisipan, terdapat 76 $(36,9 \%)$ partisipan yang termasuk ke dalam kategori dukungan sosial tinggi dan sebanyak 130 $(63,1 \%)$ partisipan termasuk ke dalam kategori dukungan sosial yang rendah. Dapat disimpulkan bahwa pada penelitian ini, mayoritas penderita lupus memiliki dukungan sosial yang rendah. 
Variabel lain yang diteliti dalam penelitian ini adalah rasa syukur. Seperti kedua variabel yang sudah dijelaskan sebelumnya, variabel rasa syukur juga dikategorisasikan menjadi dua, yaitu rasa syukur tinggi dan rendah. Berdasarkan tabel 2, dapat diketahui bahwa dari 206 partisipan, terdapat $70(34 \%)$ partisipan yang masuk ke dalam kategori tinggi dan sebanyak 136 (66\%) partisipan masuk ke dalam kategori rasa syukur rendah. Dapat disimpulkan bahwa mayoritas partisipan pada penelitian ini memiliki rasa syukur yang rendah.

Hasil dari penelitian ini menunjukkan bahwa adanya pengaruh signifikan dari penerimaan diri terhadap rasa syukur pada penderita lupus seperti yang tergambar dari tabel 3 di bawah ini. Hasil berikutnya adalah mengenai bagaimana korelasi dan koefisien determinasi dari ketiga variabel, yaitu penerimaan diri, dukungan sosial, dan rasa syukur. Ditemukan koefisien korelasi sebesar $r=0,418$. Artinya hubungan penerimaan diri, dukungan sosial, dan moderasinya cukup kuat. Selain itu, untuk koefisien determi- nasi ditemukan nilai $R^{2}=0,174, p=0,000(\mathrm{p}<$ $0,05)$. Artinya, sebesar $17,4 \%$ rasa syukur dipengaruhi oleh dukungan sosial, penerimaan diri, dan interaksi antara keduanya.

Untuk slop regresi pada X1 memiliki nilai signifikasi atau sig. $(p)=0,561(p>0,05)$, maka dinyatakan tidak signifikan. Artinya, penerimaan diri tidak berpengaruh pada rasa syukur. Kedua, slope regresi pada X2 memiliki sig. $(\mathrm{p})=$ $0,003$ ( $\mathrm{p}<0,05)$, maka dinyatakan signifikan. Artinya, secara parsial dukungan sosial berpengaruh pada rasa syukur. Hasil yang ketiga adalah uji interaksi X1X2 dengan sig. (p) = 0,045, maka dinyatakan signifikan. Artinya, dukungan sosial memoderasi antara penerimaan diri dan rasa syukur.

Dari beberapa dimensi dukungan sosial, dimensi yang paling berpengaruh adalah dimensi integrasi sosial (social integration), penghargaan diri (reassurance of worth), dan kesempatan untuk mengasihi (opportunity of nurturance). Hasil tersebut dapat dilihat pada tabel 5 .

Tabel 1.

Data Demografis Partisipan

\begin{tabular}{lcc}
\hline \multicolumn{1}{c}{ Karakteristik Penelitian } & Frekuensi & Persentasi \\
\hline Usia & 15 & $7,3 \%$ \\
$\quad$ Remaja & 141 & $68,4 \%$ \\
$\quad$ Dewasa Awal & & \\
$\quad(20-40$ tahun) & 33 & $16,0 \%$ \\
$\quad$ Dewasa Madya & & $8,3 \%$ \\
$\quad(41-50$ tahun) & 17 & \\
$\quad$ Dewasa Lanjut & & $30,6 \%$ \\
$\quad$ (51 - >60 tahun) & & $70,4 \%$ \\
Status Pernikahan & 61 & \\
Lajang & 145 & $61,7 \%$ \\
$\quad$ Menikah & & $24,8 \%$ \\
Lamanya Terdiagnosis Lupus & 127 & $13,6 \%$ \\
$\quad$ - 5 Tahun & 51 & \\
$\quad$ - 10 Tahun & 28 & \\
$>10$ Tahun & & \\
\hline
\end{tabular}

Tabel 2.

Deskripsi Penerimaan Diri, Dukungan Sosial, dan Rasa Syukur Partisipan

\begin{tabular}{|c|c|c|c|c|c|c|}
\hline Variabel & Frekuensi & Persentase & Mean & Nilai Min & $\begin{array}{l}\text { Nilai } \\
\text { Maks }\end{array}$ & SD \\
\hline Penerimaan Diri & & & & & & \\
\hline $\begin{array}{l}\text { Tinggi } \\
\text { Rendah }\end{array}$ & $\begin{array}{c}109 \\
97\end{array}$ & $\begin{array}{l}52,9 \% \\
47,1 \%\end{array}$ & 4,80 & $-16,94$ & 29,23 & 5,92 \\
\hline $\begin{array}{l}\text { Dukungan Sosial } \\
\text { Tinggi } \\
\text { Rendah }\end{array}$ & $\begin{array}{c}76 \\
130\end{array}$ & $\begin{array}{l}36,9 \% \\
63,1 \%\end{array}$ & 18,15 & $-38,01$ & 55,55 & 15,59 \\
\hline $\begin{array}{l}\text { Rasa Syukur } \\
\text { Tinggi } \\
\text { Rendah }\end{array}$ & $\begin{array}{c}70 \\
136\end{array}$ & $\begin{array}{l}34 \% \\
66 \%\end{array}$ & 27,68 & $-6,13$ & 72,11 & 15,92 \\
\hline
\end{tabular}


Tabel 3.

Uji Regresi Penerimaan Diri terhadap Rasa Syukur

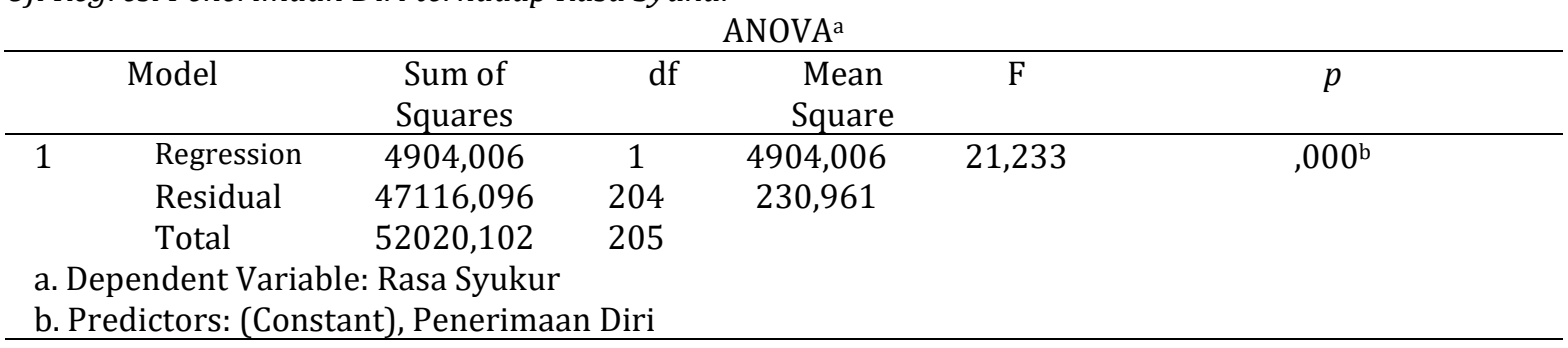

Tabel 4.

Hasil Uji Regresi Pengaruh Penerimaan Diri dan Rasa Syukur yang Dimoderasi oleh Dukungan Sosial Coefficients $^{\mathrm{a}}$

\begin{tabular}{|c|c|c|c|c|c|c|}
\hline \multirow{2}{*}{\multicolumn{2}{|c|}{ Model }} & \multicolumn{2}{|c|}{ Unstandardized Coefficients } & \multirow{2}{*}{$\begin{array}{c}\text { Standardized } \\
\text { Coefficients }\end{array}$} & \multirow[t]{2}{*}{$\mathrm{t}$} & \multirow[t]{2}{*}{$p$} \\
\hline & & $\mathrm{B}$ & Std. Error & & & \\
\hline \multirow[t]{4}{*}{1} & (Constant) & 20,456 & 1,587 & & 12,892 & ,000 \\
\hline & Penerimaan Diri & ,142 & ,244 & 053 & ,583 & ,561 \\
\hline & Dukungan Sosial & ,245 & 080 & 240 & 3,047 & ,003 \\
\hline & MODERASI & ,016 & ,008 & ,190 & 2,018 & 045 \\
\hline \multicolumn{7}{|c|}{ a. Dependent Variable: Rasa Syukur } \\
\hline
\end{tabular}

Tabel 5.

Gambaran Dimensi Dukungan Sosial

\begin{tabular}{|c|c|c|c|c|c|c|}
\hline Dimensi & Jumlah & Persentase & Mean & Nilai Min & Nilai Maks & SD \\
\hline $\begin{array}{l}\text { Kelekatan } \\
\text { Tinggi } \\
\text { Rendah }\end{array}$ & $\begin{array}{c}61 \\
145\end{array}$ & $\begin{array}{l}29,61 \% \\
70,39 \%\end{array}$ & 22,40 & $-24,05$ & 70,52 & 21,50 \\
\hline $\begin{array}{l}\text { Integrasi sosial } \\
\text { Tinggi } \\
\text { Rendah }\end{array}$ & $\begin{array}{c}153 \\
53\end{array}$ & $\begin{array}{l}74,27 \% \\
25,73 \%\end{array}$ & 20,77 & $-44,88$ & 68,87 & 22,02 \\
\hline $\begin{array}{l}\text { Bimbingan } \\
\text { Tinggi } \\
\text { Rendah }\end{array}$ & $\begin{array}{c}76 \\
130\end{array}$ & $\begin{array}{l}36,90 \% \\
63,10 \%\end{array}$ & 32,90 & $-66,62$ & 88,92 & 31,97 \\
\hline $\begin{array}{l}\text { Reliable alliance } \\
\text { Tinggi } \\
\text { Rendah }\end{array}$ & $\begin{array}{c}72 \\
134\end{array}$ & $\begin{array}{l}35,00 \% \\
65,00 \%\end{array}$ & 33,10 & $-54,22$ & 83,4 & 29,20 \\
\hline $\begin{array}{l}\text { Penghargaan dir } \\
\text { Tinggi } \\
\text { Rendah }\end{array}$ & $\begin{array}{c}135 \\
71\end{array}$ & $\begin{array}{l}65,53 \% \\
34,47 \%\end{array}$ & 20,94 & -63.35 & 77,78 & 27,29 \\
\hline $\begin{array}{l}\text { Kesempatan unt } \\
\text { mengasihi } \\
\text { Tinggi } \\
\text { Rendah }\end{array}$ & $\begin{array}{c}127 \\
79\end{array}$ & $\begin{array}{l}61,65 \% \\
38.35 \%\end{array}$ & 18,87 & $-79,98$ & 71,62 & 23,30 \\
\hline
\end{tabular}

\section{Diskusi}

Penelitian ini bertujuan untuk mengetahui apakah dukungan sosial dapat memoderasi penerimaan diri dan rasa syukur. Hasil dari penelitian ini memuat beberapa hal, yang pertama adalah mengenai penerimaan diri pada partisipan. Penerimaan diri pada penderita lupus dalam peneliti- an ini tergolong seimbang karena kelompok kategori tinggi dan rendah tidak berbeda secara signifikan. Pada penelitian ini, artinya partisipan yang memiliki penerimaan diri yang baik tidak terlepas dari bagaimana dirinya mampu melihat keadaannya saat ini. Partisipan sudah mampu menilai dirinya secara objektif sehingga ia dapat 
menyadari kelebihan dan kekurangan yang ada di dalam dirinya (Hurlock, 1976).

Dampak dari penyakit lupus berupa perubahan psikologis seperti kecewa, marah, menutup diri, dan memiliki citra diri yang rendah (Yanih, 2016) tidak terjadi signifikan pada individu yang memiliki penerimaan diri yang tinggi karena individu yang menerima dirinya akan cenderung merasa puas dengan dirinya baik mengenai keunggulan maupun keterbatasan yang dimilikinya (Novianty, 2014). Ia juga dapat menilai secara realistis bagaimana keadaannya saat ini tanpa menyalahkan orang lain atau mencela dirinya sendiri atas keterbatasan dirinya (Ardilla \& Herdiana, 2013; Permatasari, 2012). Ia justru memiliki keinginan dan kemampuan untuk mengembangkan diri sehingga dapat menjalani hidup dengan baik dan penuh tanggung jawab (Ardilla \& Herdiana, 2013). Adanya individu yang masih memiliki penerimaan diri yang rendah kemungkinan disebabkan oleh beberapa faktor. Salah satu faktor penerimaan diri adalah individu mampu memahami apa yang terjadi pada dirinya, sedangkan menurut penelitian yang dilakukan oleh Citra dan Eriany (2015) pada penderita lupus ditemukan adanya kebingungan dan tidak menyadari bagaimana kondisi dirinya, serta tidak menerima bahwa dirinya mengidap penyakit lupus. Hal tersebut menjadikan penderita lupus juga tidak bisa mengambil langkah benar yang harus ia jalani dalam kasus ini, penderita lupus sempat tidak minum obat, karena tidak merasa menderita lupus (Citra \& Eriany, 2015).

Hasil penelitian ini menunjukkan adanya pengaruh antara penerimaan diri dan rasa syukur. Pengaruh yang terjadi menunjukkan arah yang positif, artinya semakin tinggi penerimaan diri seseorang, semakin tinggi pula rasa syukur yang dimilikinya. Jika dikaitkan dengan teori yang mengatakan bahwa individu yang sudah mampu menerima dirinya, ia akan mampu mengetahui dan menyadari bagaimana keadaan dirinya secara objektif baik itu kelebihan maupun kekurangan tanpa adanya rasa marah maupun rasa bersalah pada dirinya sendiri (Ardilla \& Herdiana, 2013; Permatasari, 2012). Pemahaman tersebut juga membantu individu untuk menerima dan merasa bahwa ada hal baik yang terjadi di dalam dirinya. Hal baik tersebut tidak hanya yang baru terjadi, melainkan individu mungkin bisa mengingat atau menyadari manfaat dari apa yang pernah terjadi di masa lalu, oleh karena itu ia akan merasa bersyukur (Watkins, 2014).

Apabila dikaitkan dengan tingginya penerimaan diri yang dimiliki oleh partisipan dalam penelitian ini yaitu sebanyak $52,9 \%$, berarti partisipan dapat memiliki sikap yang positif dan mencintai orang lain (Desiningrum, 2014; Wijayanti, 2015). Ketika seseorang memiliki kasih sayang terhadap orang lain, ia akan melakukan kebaikan pula kepada orang tersebut. Hal tersebut sejalan dengan manfaat dari rasa syukur yaitu sebagai moral motivator, yang berarti dapat mendorong orang yang bersyukur untuk menolong orang lain, dan penguatan secara moral yang memungkinkan individu berbuat hal-hal yang baik dan positif (McCullough, Kilpatrick, Emmons, \& Larson, 2001).

Individu yang memiliki penerimaan diri yang baik juga akan berdampak kepada hubungannya dengan orang di sekitarnya. Pada penelitian ini, dukungan sosial partisipan tergolong rendah, artinya partisipan kurang merasakan bahwa dirinya nyaman baik psikis maupun psikologis. Perasaan untuk dicintai, diperhatikan, dan berada dalam hubungan yang saling membutuhkan juga akan kurang pada partisipan yang tergolong ke dalam kategorisasi dukungan sosial yang rendah. Di sisi lain, pada kenyataannya dalam kondisi partisipan yang mengalami banyak perubahan, justru membutuhkan dukungan yang banyak dari orangorang terdekatnya. Beberapa hal yang dirasakan penderita lupus di antaranya adalah sering kali merasa marah, kecewa, menutup diri, lebih sensitif, dan ketakutan (Sindo, 2008). Ketakutan yang muncul di antaranya adalah takut kehilangan atau mendapatkan perlakuan berbeda dari orang terdekatnya. Selain itu, jika penderita lupus dijauhkan dari lingkungannya, akan membuat dirinya merasa diasingkan, tidak berharga, rendah diri, dan perasaan negatif lainnya (Citra \& Eriany, 2015). Hal tersebut memperjelas bahwa dukungan sosial sangatlah penting untuk penderita lupus.

Dukungan sosial ini juga tidak terlepas dari bagaimana partisipan berhubungan dengan dirinya sendiri. Partisipan yang kurang mampu menerima dirinya akan cenderung menarik diri dari lingkungan dan merasa tidak diterima lingkungan (Jersild, dalam Sari \& Reza, 2013). Jika dilihat dari bagaimana ia menerima orang lain, penderita lupus yang mempunyai penerimaan diri yang baik menunjukkan sikap yang positif pada orang lain. Sedangkan yang penerimaan dirinya rendah akan cenderung membenci dirinya dan memiliki kemungkinan untuk membenci orang lain (Desiningrum, 2014; Wijayanti, 2015). Hal ini juga sejalan dengan hasil penelitian sebelumnya yang menunjukkan bahwa individu yang sudah menerima dirinya meskipun jauh dari keluarga, tetapi mampu menyesuaikan diri dengan baik dengan lingkungan, mampu membangun relasi yang baik dan terbuka akan kondisi dirinya (Citra \& Eriany, 2015).

Ketika individu mampu berbaur dengan lingkungan dan mendapatkan dukungan yang berarti dari mereka, individu merasa sudah mendapatkan kebaikan dan memiliki perasaan menyenangkan dan berterima kasih, respon terse- 
butlah yang dinamakan rasa syukur (Emmons, \& McCullough, 2004). Namun, pada penelitian ini, sebagian besar partisipan berada pada kategori rasa syukur yang rendah. Individu dengan tingkat rasa syukur yang rendah cenderung memiliki tingkat stress dan depresi yang tinggi (Wood, 2008) serta memiliki perasaan iri (Watkins, 2014). Sementara itu, Peterson dan Seligman (2004) menyatakan individu yang memiliki rasa syukur yang tinggi akan merasa berterima kasih kepada orang di sekitar keadaannya saat ini, memaknai bahwa hal baik yang ada dalam hidupnya juga berkat bantuan orang lain, dan tetap mengambil hikmah atas sesuatu yang buruk yang terjadi padanya sehingga individu tersebut masih tetap bersyukur. Seseorang yang memiliki rasa syukur yang tinggi tentu dapat menyadari dan mengakui bahwa berhasilnya ia melewati suatu keadaan yang sulit dan mendapatkan kebaikan tidak terlepas dari kehadiran orang lain di hidupnya (Watkins, 2014). Selain mengakui adanya kebaikan yang didapat dari orang lain, individu yang bersyukur juga akan lebih menghargai orang lain (Watkins, 2014).

\section{Kesimpulan}

Pada penelitian ini, mayoritas penderita lupus sebagai partisipan memiliki penerimaan diri yang relatif seimbang antara kategori tinggi dan kategori rendah. Sedangkan untuk dukungan sosial dan rasa syukur, mayoritas partisipan ada di dalam kategori rendah. Hasil lainnya menunjukkan bahwa adanya pengaruh yang signifikan antara penerimaan diri dan rasa syukur. Dukungan sosial terbukti dapat memoderasi secara signifikan hubungan antara penerimaan diri dan rasa syukur pada penderita lupus.

\section{Keterbatasan dan Saran.}

Keterbatasan dalam penelitian ini adalah karakteristik pasien lupus belum cukup spesifik. Pengambilan data dilakukan di sela-sela pasien sedang berobat, sehingga ada kemungkinan terjadi bias ketika pasien mengisi kuesioner.

\section{Daftar Pustaka}

Ardilla, F. \& Herdiana, I. (2013). Penerimaan diri pada narapidana wanita. Jurnal Psikologi Kepribadian dan Sosial, 2(1). Diunduh dari

http://journal.unair.ac.id/filerPDF/Fau ziya\%20Ardilla\%20Ringkasan.pdf

Baron, R., Bryne, D. (2000). Social psychology (9th edition). Boston: Allyn \& Bacon.

Ceyhan, A. A. \& Ceyhan, E. (2011). Investigation of university students' self-acceptance and learned resourcefulness: A longitudinal study. Higher Educ, 6(61), 649-661.

https://doi.org/10.1007/s10734-0109354-2

Citra, L. R. A. \& Eriany, P. (2015). Penerimaan diri pada remaja puteri penderita lupus. Psikodimensia, 14(1), 67-86. Diunduh dari

http://journal.unika.ac.id/index.php/ps i/article/view/374

Cutrona, C. E. \& Russell, D. (1987). Social Provisions Scale, APA PsycTests. 472479. https://doi.org/10.1037/t06213000

Desiningrum, D. R. (2014). Kesejahteraan psikologis lansia janda/duda ditinjau dari persepsi terhadap dukungan sosial dan gender. Jurnal Psikologi Universitas Diponegoro, 13(2), 102-106. https://doi.org/10.14710/jpu.13.2.102201

Emmons, R. A., McCullough, M. E. (2004). The psychology of gratitude. New York: Oxford University Press.

Figueiredo-Braga, M., Cornaby, C., Cortez, A., Pharm, M., Bernardes, M., Terroso, G., ... Poole, B. D. (2018). Depression and anxiety disorders in woman with systemic lupus erythematosus: The crosstalk between immunological, clinical, and psychosocial factors. Medicine, 97(28), e11376. https://doi.org/10.1097/MD.00000000 00011376

Fitri, N. \& Zulfan, Z. (2018). Perilaku sosial penderita lupus terhadap penyesuaian diri di kalangan masyarakat (Studi pada pasien penderita lupus di RSUDZA). Jurnal Ilmiah Mahasiswa FISIP Unsyiah, 3(1), 549-622. Diunduh dari http://jim.unsyiah.ac.id/FISIP/article/v iew $/ 6394 / 2740$.

Hernandez, P. A. (2014). The Right Reflection: Improving Women's Self- Acceptance. Tesis. Master of Applied Positive Psychology, University of Pennsylvania. Diunduh dari https://repository.upenn.edu/mapp_ca pstone/56/

Hurlock, E. (1976). Personality development. New Delhi: Tata McGraw-Hill Publishing Company Ltd.

Jordan, J., Thompson, N. J., Dunlop-Thomas, C., Lim, S. S., \& Drenkard, C. (2019). Relationships among organ damage, social support, and depression in African-American women with systemic lupus erythematosus. Lupus, 28(2), 253- 
260.

https://doi.org/10.1177/09612033188 15573

Judha, M., Nurachmah, E., \& Rachmawati, I. N. (2010). Pencarian makna hidup klien lupus eritematosus sistemik dengan perspektif Maslow dan Henderson. Jurnal Keperawatan Indonesia. 13(3), 145-152. https://doi.org/10.7454/jki.v13i3.245

Mahardika, N. F. \& Halimah, L. (2017). Hubungan gratitude dan subjective well-being odapus wanita dewasa awal di Syamsi Dhuha Foundation Bandung. PSYMPATHIC: Jurnal Ilmiah Psikologi, 4(1). 91-114. https://doi.org/10.15575/psy.v4i1.127 8

Mardiani, D. (2013, Mei 23). Penyakit lupus di Indonesia meningkat. Republika.co.id. Diunduh dari https://www.republika.co.id/berita/ga ya-hidup/infosehat/13/05/23/mn7mhx-penyakitlupus-di-indonesia-meningkat

Mazzoni, D. \& Cicognani, E. (2014). Problematic social support from patients' perspective: The case of systematic lupus erythematosus. Soc Work Health Care 53(5), 435-45. https://doi.org/10.1080/00981389.20 14.888124 .

Mazzoni, D., Cicognani, E., \& Prati, G. (2017). Health-related quality of life in systemic lupus erythematosus: A longitudinal study on the impact of problematic support and self-efficacy. Lupus, 26, 125131. https://doi.org/10.1177/09612033166 46459

McCullough, M., Kilpatrick, S., Emmons, R., \& Larson, D. (2001). Is gratitude a moral affect? Psychological Bulletin, 127 (2), 249-266.

https://doi.org/10.1037//00332909.127.2.249

McCullough, M. E., Emmons, R. A., \& Tsang, J. A. (2002). The grateful disposition: A conceptual and empirical topography. Journal of personality and social psychology, $\quad 82(1), \quad 112-127$. https://doi.org/10.1037//00223514.82.1.112

Meilinda, E. (2013). Hubungan antara penerimaan diri dan konformitas terhadap intensi merokok pada remaja di remaja. Psikoborneo, 1(1), 6-13. Diunduh dari http://e- journals.unmul.ac.id/index.php/psikone o/article/view/3273

Moses, N., Wiggers, J., Nicholas, C., \& Cockburn, J. (2005) Prevalence and correlates of perceived unmet needs of people with systemic lupus erythematosus. Patient Educ Couns, 57(1), 30-8. https://doi.org/10.1016/j.pec.2004.03. 015

Novianty, M. E. (2014). Penerimaan diri dan daya juang pada wanita penderita Systhemic Lupus Erythematosus (SLE). Psikoborneo 2(1), 28-33. Diunduh dari http://ejournals.unmul.ac.id/index.php/psikone o/article/view/3570

Nurmalasari, Y. \& Putri, D. E. (2015). Dukungan Sosial dan Harga Diri pada Remaja Penderita Lupus. Jurnal Psikologi, 8(1). Diunduh dari https://ejournal.gunadarma.ac.id/inde x.php/psiko/article/view/1290

Nurullah, A. S. (2012). Received and provided social support: A review of current evidence and future directions. American Journal of Health Studies, 27(3), 173$188 . \quad$ Diunduh dari https://papers.ssrn.com/sol3/papers.cf m?abstract_id $=2158458$

Palagini, L., Mosca, M., Tani, C., Gemignani, A., Mauri, M., \& Bombardieri, S. (2013). Depression and systemic lupus erythematosus: A systematic review. Lupus, 22(5), 409-16. https://doi.org/10.1177/09612033134 77227

Paramita, R., \& Margaretha. (2013). Pengaruh penerimaan diri terhadap penyesuaian diri penderita lupus. Jurnal Psikologi Undip, 12(1), 92-99. Diunduh dari https://ejournal.undip.ac.id/index.php/ psikologi/article/view/8341/6872

Permatasari, B. (2012). Hubungan antara penerimaan terhadap kondisi fisik dengan kecenderungan anorexia nervosa pada remaja perempuan di SMAN 1 Banjarmasin. Jurnal Psikologi Klinis Dan Kesehatan Mental, 1(2), 130137. Diunduh dari http://journal.unair.ac.id/filerPDF/110 810283_12v.pdf

Peterson, C., \& Seligman, M. (2004). Character strengths and virtues: A handbook and classification. New York: Oxford University Press.

Prasetyo, A. R. \& Kustanti, E. R. (2015). Bertahan dengan lupus: Gambaran resiliensi pada odapus. Jurnal Psikologi Universitas Dipenogoro, 13(2). 139-148. 
https://doi.org/10.14710/jpu.13.2.139148

Raafat, H. A., El Refai, R. M., Alrasheed, H. A., \& El Din, M. N. (2015). Major depression and disease activity among systemic lupus erythematosus Egyptian females. The Egyptian Rheumatologist, 37(4). S1-S6. https://doi.org/10.1016/j.ejr.2015.09.0 07

Ramzan, N., \& Rana, S. A. (2014). Expression of gratitude and subjective well-being among university teachers. Middle-East Journal of Scientific Research, 21(5), 756762. Diunduh dari https://www.idosi.org/mejsr/mejsr21( 5)14/7.pdf

Resende, O. L. C., Barbosa, M. T. S., Simões, B. F. T., \& Velasque, L. S. (2016). The representation of getting ill in adolescents with systemic lupus erythematosus. Revista Brasileira de Reumatologia (English Edition), 56(5). 398-405.

https://doi.org/10.1016/j.rbre.2016.03. 016

Ryff, C. D., \& Keyes, C. L. M. (1995). The structure of psychological well-being revisited. Journal of Personality and Social Psychology, 69(4), 719-727. https://doi.org/10.1037/00223514.69.4.719

Sarafino, E. P., \& Smith, W. S. (2010). Health psychology biopsychosocial interactions (seventh ed.). New Jersey: John Wiley \& Sons, Inc.

Sari, D. J., \& Reza, M. (2013). Hubungan antara dukungan sosial dengan penerimaan diri pada remaja penderita HIV. Character: Jurnal Penelitian Psikologi, 1(3), 1-7. Diunduh melalui https://jurnalmahasiswa.unesa.ac.id/in dex.php/character/article/view/2716

Sindo. (2008). Lupus yang Misterius. https://lifestyle.okezone.com/read/200 8/05/15/27/109464/lupus-yangmisterius.

Utami, N. M. S. N. \& Widiasavitri, P. N. (2013). Hubungan antara dukungan sosial keluarga dengan penerimaan diri individu yang mengalami asma. Jurnal Psikologi Udayana, 1(1), 12-21. https://doi.org/10.24843/JPU.2013.v0 1.i01.p02

Watkins, P. C. (2014). Gratitude and the good life toward a psychology of appreciation. Dordrecht: Springer.

Wijayanti, D. (2015). Subjective well-being dan penerimaan diri ibu yang memiliki anak down syndrome. Psikoborneo, 3(1), 224238. Diunduh dari http://ejournals.unmul.ac.id/index.php/psikone o/article/view/3774

Wood, A. M. (2008). Individual differences in gratitude and their relationship with well-being. Disertasi Doktoral. Departement of Psychology, University of Warwick. Diunduh dari http://wrap.warwick.ac.uk/2513/1/W RAP_THESIS_Wood_2008.pdf

Yanih, I. (2016). Quality of life in patient with systemic lupus erythematosus (SLE). Jurnal Berkala Epidemiologi, 4(1). 1-12. https://doi.org/10.20473/jbe.V4I1201 6.1-12 